\title{
КАТЕГОРІЯ ВІДМІНКА В АСПЕКТІ АКСІОЛОГІЧНОЇ ПРАГМАЛІНГВІСТИКИ (на матеріалі української та російської мов)
}

\footnotetext{
Халіман О.В. Категорія відмінка в аспекті аксіологічної прагмалінгвістики (на матеріалі української та російської мов).

У статті схарактеризовано можливості граматичного значення (ГЗ) відмінка як морфологічного засобу вираження оцінки в сучасних українській та російській мовах.

Ключові слова: граматичне значення відмінка, оцінка, українська мова, російська мова.
}

Халиман О. В. Категория падежа в аспекте аксиологической прагмалингвистики (на материале современных украинского и русского языков).

В статье охарактеризованы возможности грамматического значения (ГЗ) падежа как морфологического средства выражения оценки в современных украинском и русском языках.

Ключевые слова: грамматическое значение падежа, оценка, украинский язык, русский язык.

Khaliman O. V. The category of case from the aspect of the axiological pragmalinguistics (on the base of Ukrainian and Russian languages).

The potential of the grammatical meaning (GM) of case as a morphological means of the expression of estimation in Contemporary Ukrainian and Russian languages are characterised in the article.

Key words: grammatical meaning of case, estimation, Ukrainian language, Russian language.

На сучасному етапі розвитку лінгвістики в аспекті комунікативнопрагматичних досліджень особливий інтерес мовознавців викликає категорія оцінки. При цьому увагу сфокусовано на вивченні особливостей ціннісної картини світу носіїв мови та вербалізації оцінки з огляду на оцінний потенціал мовних одиниць.

Сутність лінгвофілософської категорії оцінки та характер ії мовної презентації активно вивчали вітчизняні й зарубіжні мовознавці. Дослідження вчених стосувалися особливостей вираження оцінки одиницями різних мовних рівнів (лексико-семантичного - Т. Вільчинська,
В. Іващенко,
Т. Космеда,
Н. Левадна,
Ф. Моісєєнко,
В. Труб, словотвірного - І. Ковалик, Т. Космеда, Л. Летюча, В. Лопатін, А. Нелюба, О. Олексенко, Л. Родніна, Т. Черторизька, В. Шинкарук, Л. Шутак, фразеологічного - В. Ужченко, Л. Авксентьєв, А. Івченко, Н. Грозян, Т. Космеда, С. Олійник, специфіки частиномовного розшарування лексики 3 оцінною семантикою - Т. Денисюк, О. Жижома, I. Кононенко, Т. Космеда, Н. Левадна, Л. Мацько, Г. Монастирецька, О. Наконечна, С. Равлюк, Г. Серпутько, С. Педченко, В. Ткачук та відповідних синтаксичних конструкцій - В. Мараховська, М. Ретунська, О. Семенюк, П. Ткач, С. Шабат, І. Шкіцька), оцінки як текстової (дискурсивної) категорії (О. Вольф, Т. Космеда, молоді науковці М. Кайки, М. Михальченко) у дискурсах різного функційного призначення, напр., художньому - У. Соловій, епістолярному - Н. Павлик, публіцистичному Л. Гусліста, Н. Кочукова, С. Равлюк, І. Онищенко, науковому - 
Ж. Краснобаєва-Чорна, політичному - К. Серажим, рекламному - В. Зірка, Ю. Булик, розмовному мовленні - В. Труб; концептів як репрезентантів аксіологічної інформації (Т. Вільчинська, Т. Космеда, Н. Плотнікова, А. Приходько, Ю. Шамраєва) та ін. Функційно-прагматична спрямованість сучасних лінгвістичних досліджень відкрила можливості для вивчення нових аспектів категорії оцінки. Аналіз функційної специфіки граматичних одиниць дав змогу мовознавцям закцентувати увагу на їх прагматичній значущості в комунікативному процесі. Спираючись на засади лінгвістичного функціоналізму, що є основою граматики активного типу (праці В. Виноградова, Л. Щерби, Р. Якобсона, О. Бондарка, Ф. Бацевича, I. Вихованця, К. Городенської, Н. Гуйванюк, Г. Золотової, А. Загнітка, Т. Космеди, О. Кубрякової, О. Ремчукової та ін.), учені почали досліджувати граматичні одиниці i як засоби вираження оцінки, співвідносячи їх структурні особливості з комунікативним процесом. Ці дослідження мотивують необхідність розробки «граматики оцінки» усебічного аналізу системи граматичних засобів вираження оцінних значень 3 урахуванням їхніх прагматичних характеристик. Як відповідний крок до створення такого комплексного опису авторкою цієї статті вже було схарактеризовано ГЗ роду й числа як засоби вираження оцінки в сучасній українській мові [27].

Мета цієї наукової розвідки - на матеріалі сучасних української та російської мов з'ясувати й схарактеризувати можливості ГЗ відмінка як морфологічного засобу вираження оцінки.

Предмет, названий іменником, виявляє себе не лише через свої внутрішні якісні та кількісні ознаки, а й через зовнішні, коли він вступає у відношення з іншими фактами довкілля, що знаходить своє узагальнене відображення в граматичних фактах мови, у зв'язках назви предмета 3 іншими словами, що реалізується певним оформленням слова. Оформлення назви предмета залежить від характеру виражених відношень, що «стають змістом граматичної категорії відмінка» [18, с. 52-53] граматичної словозмінної категорії імені, яка виражає його синтаксичне відношення до інших слів у словосполученні чи реченні. Зовнішніх відношень між фактами довкілля значно більше, ніж внутрішніх. Тому ГЗ у межах граматичної категорії відмінка набагато більше, ніж ГЗ у межах інших граматичних категорій. Крім того, кожне ГЗ відмінка (кожний відмінок) має кілька часткових значень, чим відрізняється від ГЗ інших граматичних категорій, що, як правило, однозначні [18, с. 53].

Відносячи відмінок до категорій, оцінний потенціал яких мінімальний, В. Лопатін усе ж виділяє оцінну функцію, характерну для родового партитивного, що вказує на високу інтенсивність ознаки чи іiі повну відсутність, порівн. (рос.): Народу-то; Билетов - ни одного [19, с. 72] (аналогічно в перекладі укр.: Народу-то; Квитків - жодного). 
Така обмеженість у можливостях вираження оцінних значень зумовлена специфікою категорії відмінка, про що, наприклад, пише О. Безпояско: на відміну від категорійних парадигм особи, часу, способу, стану, частково роду та ін., у яких форми - носії сем, об'єднані родовим категорійним значенням, що $\epsilon$ інваріантом кожної семи, «кожен відмінковий афікс протиставлений усім іншим тільки формально» [2, с. 9].

Відмінкові форми іменника слугують в українській мові для вираження різних значень - кожна відмінкова форма є носієм таких сем, що не інтегруються в єдину категорію. Але водночас кожна відмінкова сема зараховує всі відмінкові форми іменника до єдиного категорійного значення предметності, кожна відмінкова форма прикметника - до єдиного категорійного значення статичної ознаки. Отже, формальним втіленням категорії предметності - визначальної ознаки іменника як частини мови - $\epsilon$ відмінкова парадигма, але в ній, на відміну від парадигм часу, способу, стану дієслова та ін., семи окремих форм протиставляються не за однією ознакою (предметності), а за різними, ій підпорядкованими: діяча, об'єкта, статичної ознаки та ін. [2, с. 9].

Із цього висновкуємо, що саме відмінку притаманна найпослідовніше виражена порівняно 3 іншими морфологічними категоріями іменника семантична спеціалізація [5], у зв'язку із чим гра, маніпуляція відмінковими формами, їх транспозиція у сферу вживань опозиційних одиниць практично неможлива, оскільки складові категорії відмінка й не утворюють таких опозицій.

Підтверджують цю тезу міркування Є. Шендельс, що, досліджуючи процес нейтралізації граматичних опозицій як наслідок транспозиції одного члена категорії в область уживання іншого, приходить до висновку, що така нейтралізація неможлива для тих форм, що безпосередньо не протиставляються одна одній, зокрема розглядає як такі в російській мові шестичленну й восьмичленну опозиції [29, с. 15].

Лексичне значення (ЛЗ) іменника виступає у нерозривному зв'язку з ГЗ відмінка $[17$, с. 6]. Сутність відмінка, як наголошують дослідники, одночасно і морфологічна, й синтаксична (зміна відмінкової форми разом з тим $є$ зміною синтаксичної функції іменника $[18$, с. 54]; відмінок «впливає на семантикосинтаксичну структуру речення, чого не здійснюють категорії роду та числа» $[2$, с. 21]), «однак не семантична, бо ЛЗ іменника в усіх відмінках те саме» [9, с. 195]. На це ж указує й І. Кучеренко: у кожній із відмінкових форм, в яких іменник виступає в реченні, виражаючи певне відношення названого ним (речі, предмета, особи) до інших предметів і явищ, він має одне значення - семантика його (реальне ЛЗ) не змінюється [17, с. 9].

Такі твердження (неможливість транспозиції для утворення ігрем за участю ГЗ відмінка, стале ЛЗ різних відмінкових форм) спонукають до висновку про неможливість з'яви в ЛЗ слова оцінних сем, що породжувалося б маніпуляцією ГЗ відмінка. 
Проте можливим $\epsilon$ породження оцінки шляхом утворення неправильних відмінкових форм. Це можливо там, де $\epsilon$ своєрідна варіативність й, відповідно, вибір відмінкових закінчень через наявність суміжних парадигм. Окремої уваги заслуговують випадки вживань, коли мовці, використовуючи невідмінювані іменники, починають застосовувати щодо них певну парадигму відмінювання, що «надає мовленню комічного звучання» [7, с. 237]. Учені наголошують, що відмінюваність слів письменники використовують як засіб художньої виразності саме тоді, коли персонажі починають відмінювати слова, порушуючи норми літературної мови. Уживання в мовленні персонажів спотворених відмінкових форм, що розглядаються як безграмотні (порівн., (рос.): местов, делов, блюдов і т. ін. [10, с. 321]), цілком закономірне. Художники слова прагнуть відтворити неправильність у мовленні героїв, що віддають перевагу просторіччю, як засіб яскравої мовленнєвої характеристики людини низької культури, напр. (рос.): Подвиньтесь! Вам говорят! Дайте мадаме место! [цит. за: 10, с. 321]; [Фамусов]...Да не в мадаме сила [цит. за: 7, с. 237].

Як демонструє аналізований фактичний матеріал, необхідно розмежовувати такі відмінні вживання: по-перше, навмисні порушення при відмінюванні іменників, що породжують відповідні ігреми для вираження іронії, оцінки (ігрема виникає як наслідок маніпуляції ГЗ відмінка, що змінює граматичні ознаки слова й сприяє породженню прагматичної оцінної інформації), і по-друге, що, як було зазначено, спостерігаємо зокрема в художній літературі, - негативна оцінка персонажа через його неграмотність - порушення відмінкових норм (таке порушення ігрему не сформувало, негативно оцінюється сам мовець через таке порушення).

Серед інших перетворень морфологічної форми слова О. Земська на матеріалі російської мови розглядає неправильне утворення відмінкових форм, що слугує для породження жартів, порівн. (рос.): $A$. У него губы как у Кобзона// Б. Не знаю ни Кобзона/ ни его губей // [24, с. 179]. Названа дослідниця також характеризує як найпростіший і найпоширеніший спосіб мовної гри так званий прийом мовленнєвої маски, який полягає в тому, що мовець навмисно говорить незвично, як хто-небудь. Використовуючи цей прийом, зазвичай не турбуються про повне відтворення чужого мовлення, лише кидають окремі «яскраві мазки», найбільш характерні ознаки чужого голосу. Мовець досягає експресивності, намагаючись зробити своє мовлення незвичним для даної ситуації. Ефект комізму створюється контрастом між ситуацією, контекстом і ознаками чужого мовлення, що викликають уявлення про інших мовців та іншу ситуацію [24, с. 180]. Прийом може бути використано і як характерологічний, оцінний засіб (для зображення людини), тоді він отримує смислове навантаження й переходить у сферу гострослів'я, дотепності й слугує частіше для вираження негативної оцінки. Найпоширеніші на сьогодні, як зазначає О. Земська, ігрові маски 
малокультурного простачка (гра на діалектах і просторіччі) та бюрократа (гра на канцеляризмах) [24, с. 180]. Застосування першої, як спостерігаємо, можливо й за участю ГЗ відмінка, порівн. (укр.): - А щее подаруємо квіти... - О-о-о, обов'язково, багато ромашків, трояндів (з мовлення того, про кого йдеться) (з розм. мовл).

Проте у віршованому тексті бачимо, що таке ж порушення не зумовлює з'яву додаткової конотації, оскільки використовується для дотримання законів віршобудови, напр. (укр.): Загубилася любов між нами, Як вітер серед спілих трав. Загубилася між пелюстками Трояндів, щзо їх дарував [20].

Приклади підтверджують: мовці іронізують, порушуючи іменникову невідмінюваність, напр. (укр.): A поӥдемо куме на метрі покатаємось? [23]. Цей засіб українці скеровують на анекдоти, що стає яскравим засобом створення гумористичного ефекту (укр.): Україна. Автобус. До самотньо сидячої, смутної, утомленої жінки звертається чоловік: - Dode pa?. Bсе золото миру не світить яскравіше, ніж вона в цую мить! Француз!! Справжній ФРАНЦУЗ У Ї̈ ЖИТТІ!!! Всі, кінецьь сірим будням! Прощуайте, украӥнські чоловіки зі свойми хокеями, риболовлями й розкиданими носками. Тепер будуть шампанське й танго в підніжжя Ейфелевої вежі, сонце й білий морський пісок. I, зрозуміло, Шанель! Але! Але треба ж щзось відповісти!: Пардон мсьє! Кес ке се? - Автобус, питаю, до депа йде? [26]. Як засіб негативної оцінки в анекдоті також використано ГЗ числа: синтаксичний фразеологізм зі значенням узагальнювальної множинності: українські чоловіки зі своӥми хокеями, риболовлями й розкиданими носками.

Цікавим $є$ вживання словосполучення кіна не буде, що його використовують у сучасній комунікації як усталене, де одним із засобів породження оцінки $є$ змінена форма невідмінюваного іменника. Висловлювання вживають у переносному значенні, що частіше вказує на негативну оцінку чогось, що не відбулося, відмінилося й т. ін. Спостерігаємо подібні вживання в публіцистиці (часто в газетних заголовках), де подана далі інформація підтверджує вираження негативу, порівн. (укр.): Кіна не буде. Бізнес розвалився [12]; «Кіна не буде - касета пожсована». Від провокачій Олега Ляика втомилися навіть колеги по БЮТу [14]; Кіна не буде. Б’ютівська провокаџія з ТВК не вдалася [13]; Кіна не буде - права скінчилися. Під час поӥздки на автобусі багато пасажирів мимоволі стають причетними до порушень права інтелектуальної власності [15] і т. ін. Аналогічно аналізовану фразу використовують у російській мові, напр.: Украинский кинематограф: кина не будет? «Хм! У вас потрясающиая профессия! Вы занимаетесь тем, чего нет» [21]. Отже, як бачимо, використовуючи прецедентний негативнооцінний зміст висловлювання кіна не буде, що сформувався і за участю ГЗ відмінка, журналісти налаштовують читача на очікування інформації негативного характеру. 
Додаткового коментаря потребує вживання згаданої вище лексеми мадам, де спостерігаємо одночасне застосування кількох засобів вираження оцінки, їх аплікацію при функціюванні такого типу слів у сучасній комунікації. Досліджуючи агентивні імена морально-етичної оцінки, серед інших семантичних груп підсистеми назв особи Т. Космеда виділяє іменники-назви осіб «за соціальним статусом чи походженням». Як зазначає названа дослідниця, багато із слів цієї групи втратили свої основні значення, причому переносні значення витіснили основні [16, с. 251]. Слова, вжиті в переносному значенні, вплітаючись у смислову канву тексту, «слугують образним засобом створення сатири й гумору, ефективним прагматичним засобом, оскільки викликають у читача певну реакцію: відчуття обурення, зневаги, ненависті, співчуття, схвалення» і т. ін. [16, с. 252].

Навмисне відмінювання невідмінюваного іменника мадам стає засобом підсилення оцінки як в українській, так і в російській мовах, напр.: Кролика Сєню бачили на Золотих, з якоюсь мадамою по бутіках шаривсь крайну рятував [8]; ...хахаха ...mа не з иією мадамою йому нічо не світить!!! [6]; А Біличка з отією мадамою-утконосом усе у кадр пнуться [1]; А хто ж стоїть за Юлькою? А за иією мадамою стоять торгаші, торгаші без роду-племені... [22]; Но вскоре признался, что не любит меня и начал встречаться с другой девушкой. Много нервов он испортил мне с этой мадамой. То к ней уйдёт, то ко мне вернётся [3].

Як наголошує І. Голуб, пояснення потребує і факт відмінювання власних назв [7, с. 235]. Норма щодо невідмінювання деяких прізвищ існувала не завжди, в XIX ст. були можливі варіанти, відголоски чого впливають і на сучасне вживання таких іменників. У розмовному мовленні можна зустріти відмінювані форми жіночих українських прізвищ на -ко [7, с. 236]. Такі відхилення від мовної норми можуть бути цілком виправдані прагматичними цілями комунікації - вираження незадоволення, іронії, негативної оцінки, порівн..: Я за Федірку працювати не збираюсь (з розм. мовл.); Та від Зарудки ти нічого не доб'єшся (з розм. мовл.); От і спитаєш Рибалку, для чого вона цее робить (з розм. мовл.). 3 відповідною метою спостерігаємо спотворення навіть форми називного відмінка: Щось останнім часом Федірка дуже розумна (з розм. мовл.).

Оригінальним є те, що деякі прислівники утворюють відмінкові форми за аналогією з іменниками [4, с. 106] (укр.): Ти сюдюю, я тудою, $A$ зійдемось над водою (Леся Українка); Чи не бачив парубка і дівки, чи не йшли сюдою (І. Рудченко); Ми дивимося кудою до нори ближче (І. Рудченко); Ото якось там купиі знову їхали тудою, та й до ӥх зайхали (I. Рудченко) [цит. за: 4, с. 106]. У наведених контекстах такі форми не пов'язані зі зміною значення, зокрема з вираженням оцінки, проте й такий засіб може бути використано в художньому тексті для негативної характеристик героя через неправильність його мовлення. 
При утворенні оказіональних граматичних форм в українській та російській мовах можливою $\epsilon$ одночасна маніпуляція кількома граматичними засобами, порівн.: Народе! Врешті спинимось. Ставати квазімодами. Ходімо прямоспинними, Щоб завжди бути гордими [25], С квазимодами уже дуэтом поет и клипы снимает... (про Ірину Білик) [11]. У наведених прикладах при утворенні відонімної множинної форми (узагальнювальна множинність - гра ГЗ числа) порушується ще одна граматична ознака - невідмінюваність, тобто у породженні оцінки беруть участь ГЗ і числа, й відмінка. При вживанні наведеної вище множинної форми в конструкції «хтось (ім. чол. роду) у спіднииіi» [Див. про це: 27, с. 8] (напр. (укр.): ... все ж таки клопіт, а з другого боку, може й подобалось, себто подобались майбутні няньки: «Не пришле ж вона мені якихсь квазімодів у спідницях», - міркував він і помилився [28]) долучається й ГЗ роду: застосування мовцем прецедентної інформації, пов’язаної з носієм власної назви - чоловіком, щодо осіб жіночої статі.

Отже, у сучасних українській та російській мовах за кожним відмінком історично закріпилось певне категорійне значення. Своєрідність відмінка як категорії зумовлює обмеженість його участі в породженні оцінки через неможливість сміливих транспозицій відмінкових грамем у зв'язку з їхньою вузькою семантичною специфікою. Аналіз демонструє функціонування аналогічних механізмів породження оцінки за участю ГЗ відмінка в досліджуваних мовах. Виникнення ігрем для вираження оцінки як вторинної функції ГЗ відмінка можливе при цілеспрямованому утворенні неправильних відмінкових форм відмінюваних і невідмінюваних слів. Цей же засіб також може бути використано як оцінний при створенні певного образу, наприклад, у художній літературі: порушення норм утворення відмінкових форм, що не $є з$ боку мовця цілеспрямованим i відповідних ігрем не формує, характеризує його негативно.

Перспектива дослідження - аналіз у виокремленому ракурсі інших граматичних категорій української мови для створення цілісної теорії «граматики оцінки». Порівняння 3 російською та іншими мовами дасть змогу виокремити специфіку, характерну для української мови.

1. Альо, ми шукаєм таланти [Електронний ресурс] Блог про агресивний несмак українського бомонду і не тільки. - Режим доступу : http://ragu.li/post/alomy-shukajem-talanty/.

2. Безпояско О. К. Граматика української мови. Морфологія : [підручник] / О. К. Безпояско, К. Г. Городенська, В. М. Русанівський. - К. : Либідь, 1993. - 336 с.

3. Безумная любовь [Электронный ресурс] // Жемчужины мысли. - 2011. - 27 сентября. - Режим доступу : http://www.inpearls.ru/comments/133061.

4. Ващенко В.С. Стилістична морфологія української мови : [навч. посібн. зі стил.] / В. С. Ващенко. - Дніпропетровськ : ДДУ, 1970. - 87 с.

5. Вихованець І. Р. Система відмінків української мови / I. Р. Вихованець. - К. : Наукова думка, 1987. $-232 \mathrm{c}$.

6. В контакті [Електронний ресурс]. - Режим доступу : http://vkontakte.ru/id8126459. 
7. Голуб И. Б. Стилистика современного русского языка : [уч. пособ. для вузов по спец. «Журналистика»] / И. Б. Голуб. - М. : Айрис-пресс, 2003. - 442 с.

8. Гуртомівка. 24 серпня 2010 року (Київ) [Електронний ресурс] // Hurtom-торрент-толока : форум. Режим доступу : http://toloka.hurtom.com/viewtopic.php?p=218075.

9. Дудик С. П. Силістика української мови : [навч. посіб.] / С. П. Дудик. - К. : ВЦ «Академія», 2005. - 368 с.

10. Ефимов А. И. Стилистика художественной речи / А. И. Ефимов. - [2-е изд., доп. и перераб.] - М. : Изд. Моск. ун-та, 1961. - 519 с.

11. Ирина Билык сменила имидж ради съемок в видео группы ТІК [Електронний ресурс] // Ivona. 2011. - 06 сентября. - Режим доступа : http://ivona.bigmir.net/showbiz/stars/317746-Irina-Bilyk-smenilaimidzh-radi-s-emok-v-video-gruppy-T-K.

12. Кіна не буде. Бізнес розвалився [Електронний ресурс] // Власна справа. - Режим доступу : http://www.vlasnasprava.info/ua/business_az/how_to_grow/losers.html?_m=publications\&_t=rec\&id=685.

13. Кіна не буде. Б'ютівська провокація 3 ТВК не вдалася [Електронний ресурс] // Новини Закарпаття. Mukachevo net. - 2009. - 25 червня. - Режим доступу : http://www.mukachevo.net/ua/news/view/21306-\%D0\%BA\%D1\%96\%D0\%BD\%D0\%B0-\%D0\%BD\%D0\%B5$\% \mathrm{D} 0 \% \mathrm{~B} 1 \% \mathrm{D} 1 \% 83 \% \mathrm{D} 0 \% \mathrm{~B} 4 \% \mathrm{D} 0 \% \mathrm{~B} 5$.

14. «Кіна не буде - касета пожована». Від провокацій Олега Ляшка втомилися навіть колеги по БЮТу [Електронний ресурс] // Товариш. Сайт українських соціалістів. - 2006. - 22-25 вересня. №76(866). - Режим доступу : http://www.tovarish.com.ua/archive/866/vtoraia_po/Kina_ne_bu.html.

15. Кіна не буде - права скінчилися [Електронний ресурс] // Patent. - 2006. - 26 червня. - Режим доступу : http://patent.km.ua/ukr/articles/i901.

16. Космеда Т. А. Функционально-семасиологичкское исследование имен предметно-признаковой семантики // Бацевич Ф. С. Очерки по функциональной лексикологии / Ф. С. Бацевич, Т. А. Космеда. Львов : Свит, 1997. - С. 209-351.

17. Кучеренко І. К. Категорія відмінка в сучасній українській мові / I. К. Кучеренко. - Львів : Видавн. Льв. ун-ту, 1961. - 52 с.

18. Леонова М. В. Сучасна українська літературна мова. Морфологія : [навч. посібн.] / М. В. Леонова. - К. : Вища школа, 1983. - 264 с.

19. Лопатин В. В. Оценка как объект грамматики / В. В. Лопатин // Русский язык : проблемы грамматической семантики и оценочные факторы в языке : Виноградовские чтения. - М. : Наука, 1992. C. $70-75$.

20. Наше : тексти пісень [Електронний ресурс]. - Режим доступу : http://nashe.com.ua/song.htm?id=9185.

21. Орестов А. Украинский кинематограф: кина не будет? [Электронный ресурс] // Вечерние Вести. - 2011. - 25 серпня. - Режим доступу : http:/gazetavv.com/analytics/28623-ukrainskiy-kinematograf-kina-nebudet.html.

22. Про одне пророцтво [Електронний ресурс] // Форум Дурдом. - Режим доступу : http://forum.durdom.in.ua/viewtopic.php?f=1\&t=53912\&p=968415.

23. Рупор фракции Понаехавших [Електронний ресурс]. - 2011. - 29 березня. - Режим доступу : http://www.moswar.org/main/83-a-poyidemo-kume-na-metr-pokatayemos.html.

24. Русская разговорная речь : Фонетика. Морфология. Лексика. Жест / [под. ред. Е. А. Земской]. М. : Наука, 1983. - 238 с.

25. Савчук М. Цілюща метафора [Електронний ресурс] // Клуб поезії. - Режим доступу : http://www.poetryclub.com.ua/getpoem.php?id=207689.

26. Українські анекдоти [Електронний ресурс]. - Режим доступу : http://ukr-anecdotes.com/rozdil/proteshhu/page/16.

27. Халіман О. В. Морфологічні засоби вираження категорії оцінки в сучасній українській мові : рід і число : автореф. дис. на здобуття наук. ступеня канд. філол. наук : спец. 10.02.01. «Українська мова» / О. В. Халіман. - Х., 2011. - 20 с.

28. Шевченко Т. Нещасний [Електронний ресурс] // Український Центр. - Режим доступу : http://www.ukrcenter.com/Лiтература/Тарас-Шевченко.

29. Шендельс Е. И. Многозначность и синонимия в грамматике / Е. И. Шендельс. - М. : Высш. школа, 1970. - 204 с.

Стаття надійшла до редакції 25.11.2011 p. 